International
International Archives of Medicine

Section: Primary CAre ISSN: 1755-7682
Vol. 9 No. 285 doi: $10.3823 / 2156$

\section{Dietary Patterns of Pre-Schoolers and Their Relationship with Food Insecurity}

Élida Mara Braga Rocha1, Luiz Carlos de Abreu ${ }^{2}$, Patricia Dore Vieira², Isabel Cristina Esposito Sorpreso ${ }^{2}$, Sophia Cornbluth Szarfarc ${ }^{1}$

1 Departamento de Nutrição. Faculdade de Saúde Pública da Universidade de São Paulo, SP, Brazil.

2 Laboratório de Delineamento de Estudos e Escrita Científica da Faculdade de Medicina do ABC, Santo André, São Paulo, Brazil.

food and nutrients of a population. Research in this area is very important to evaluate eating habits, especially during the critical period of growth and development in childhood.

Objective: Analyse the dietary patterns of pre-school children in a city with a Human Development Index (HDI) of 0.800, their relationship to socio-economic conditions, household FI and overweight children.

Methods: A cross-sectional study was undertaken of 308 children between 24 and 48 months of age enrolled at municipal day care centres in a city with a Human Development Index (HDI) of 0.800 . Dietary intake was assessed using a food frequency questionnaire and interpreted through principal components analysis (PCA). Nutritional condition was assessed by the indicator BMI/age and food insecurity (FI) was classified by the score on the Brazilian Food Insecurity Scale.

Results: Five DPs were identified: "Western", "Fruits and vegetables", "Prudent", "Dairy" and "Traditional". Pre-schoolers with "Western" food standards are less likely (OR: $0.51 ; 95 \% \mathrm{Cl}: 0.27-0.98)$ to be in moderate or severe $\mathrm{Fl}$; however, food quality is compromised, featuring light FI. Children in the "Traditional" category are strongly linked to families receiving social benefits and childhood overweight $(p<0.05)$.

Conclusion: Western and Traditional DPs are qualitatively and quantitatively inadequate, regardless of family income condition and maternal education. Thus, public actions to combat unfavourable DPs and deleterious effects on health are important and indispensable to prevent chronic diseases.

\section{Keywords}

Dietary Patterns; Food Security; Overweight; Preschool; Food Consumption. 


\section{Introduction}

Inappropriate eating habits formed in early childhood can be retained in the next stages of life, providing greater risk of the development of chronic diseases [1], as in the case of overweight/obesity. The economic consequences in terms of the increase in health costs in the private and public sector, in addition to dramatic implications for the survival of the individual, justify the epidemiological value of research to public health.

The investigation of dietary patterns (DPs) in different regions and cultures is necessary for the evaluation of eating habits and their short- and long-term outcomes in the health of the population, these being a better predictor of disease risk than the isolated effect of nutrients or foods [2].

Some studies have linked obesity and socioeconomic conditions [3,4] and others have investigated the DPs of pre-school children $[1,5,6]$, but few have attempted to discuss these variables in conjunction with household food insecurity (FI) in pre-schoolers, an important population group as an indicator of the quality of life and health of a country.

Therefore, this objective is analyse the dietary patterns of pre-school children in a city with a Human Development Index (HDI) of 0.800, their relationship to socio-economic conditions, household FI and overweight children.

\section{Methods}

This is a cross-sectional study with children enrolled in public day care centres in the city of Taubaté, State of São Paulo, Brazil, in 2014. The probabilistic sample was based on the total number of children enrolled in public service education, which corresponds to approximately $80 \%$ of the total population of children with less than five years of age. For the sample calculation, a prevalence of $22.6 \%$ of food insecurity was taken from a national survey [7], were adopted $\alpha=5 \%, \beta=20 \%$ (80\% statistical power) and an increment of $10 \%$ for possible losses, resulting in a sample of 291 children. The sample for the analysis of DPs was made up of data from 308 children who completed all the activities planned for the project.

Socioeconomic information was obtained through a questionnaire sent by the day care centres to parents. It consisted of the following information: age and gender of the child, maternal education in complete years of schooling, receipt and value of social benefits through conditional income transfer (Programa Bolsa Família - PBF) and monthly family income, converted into minimum wages considering the value of the time (2014) of $\mathrm{R} \$ 724.00$.

Household food insecurity (FI) was evaluated using the Brazilian Food Insecurity Scale (Escala Brasileira de Insegurança Alimentar - EBIA), which classifies the families into four categories according to scores of ranging from 0 to 15 in families with children under 18 years, as follows: 0 points - food security (FS); 1 to 5 points - mild FI (when there is the worry of running out of food to ensure the immediate future, or qualitative impairment in terms of financial limitations on diet); 6 to 10 points - moderate $\mathrm{FI}$ (with qualitative and quantitative restrictions on diet among adults); 11 to 15 points - severe FI (the restriction in the diet is qualitative and quantitative for adults and children) [8].

The anthropometric assessment used measures of weight and height, according to the technical standards of the World Health Organization (WHO), adopted by the Brazilian Health Ministry [9]. The nutritional condition was evaluated by body mass index/age (BMI/A) and for the determination of excess weight (overweight/obesity), z scores $\geq+2.00$ [10] were considered.

Food consumption was obtained using a food frequency questionnaire developed to assess the usual diet of children [11], containing a frequency of consumption presented in 7 categories: never; less than 1 time per month; 1 to 3 times per month; 1 time per week; 2 to 4 times a week; 1 time per 
day; 2 or more times per day. This corresponded to the children's food consumption over the previous 6 months.

To obtain the DPs, exploratory factor analysis (EFA) was used, with the extraction of factors being undertaken through principal components analysis (PCA). In this way, from the list of 57 food items in the Food Frequency Questionnaire, 26 food groups were built, based on criteria concerning nutritional composition and cultural aspects (Table 1). Items consumed with less than $20 \%$ weekly frequency were excluded; foods with a weekly consumption of more than $80 \%$ (rice, beans, chicken, fish, eggs, milk, chips, cake, instant noodles and coffee) were added individually to allow better analysis of children's food consumption habits. For the factor analysis, KaiserMeyer-Olkin $(\mathrm{KMO}) \geq 0.600$ and Barlett's test of sphericity (BTS) p > 0.05 were considered to indicate the suitability of the sample.

Sequentially, orthogonal rotation was carried out to optimize the configuration of DPs, considering factor loadings greater than 0.40 to be acceptable. The number of extracted factors explained around $40 \%$ of total variance, confirming the observations of the Cattel graph (scree plot). Cronbach's alpha was calculated to analyse internal consistency, attaining acceptable values $\geq 0.60$.

After obtaining the DPs, the scores were categorized according to the 50 percentile (P50), where < P50 represented low consumption and $\geq$ P50 high consumption. The cut-off point given by the median for each food pattern was 0.010 (default 1), 0.018 (default 2), 0.137 (default 3), 0.168 (default 4) and 0.082 (default 5).

Logistic regression analysis was used to assess the socioeconomic determinants of $\mathrm{Fl}$ and the nutritional status of all DPs. First, the independent variables that presented values of $p<0.2$ in the Chi-square test were included in the model, taking into account the calculation of the odds ratio (OR) and adjusted with their respective 95\% confidence intervals ( $\mathrm{Cl}$ : $95 \%$ ) and considering values of $p<0.05$ to be sta-
Table 1. Food groups and items from the food frequency questionnaire used in the factorial assessment of the main components.

\begin{tabular}{|c|c|}
\hline Group or food & $\begin{array}{l}\text { Food present in the food frequency } \\
\text { questionnaire }\end{array}$ \\
\hline Rice & Boiled rice \\
\hline Beans & Boiled beans \\
\hline Pasta & Boiled noodles, pasta with tomato sauce \\
\hline Instant noodles & Miojoß instant noodles \\
\hline Vegetables & $\begin{array}{l}\text { Lettuce, tomato, chard, arugula and } \\
\text { cabbage }\end{array}$ \\
\hline Legumes & $\begin{array}{l}\text { Pumpkin, carrots, chayote, soups with } \\
\text { legumes }\end{array}$ \\
\hline Tubers & Boiled potato or puree, manioc \\
\hline Fruits & $\begin{array}{l}\text { Banana, apple, pear, orange, orange } \\
\text { juice, fruit juice (passion fruit, pineapple, } \\
\text { lemon...) }\end{array}$ \\
\hline Meats & Boiled beef (cooking or minced) \\
\hline Chicken & Boiled, fried, grilled or roasted chicken \\
\hline Fish & Boiled or fried fish \\
\hline Eggs & $\begin{array}{l}\text { Boiled or fried eggs, omelette with one } \\
\text { egg }\end{array}$ \\
\hline Sausages & Sausage, ham, mortadella \\
\hline Milk & Whole milk, whole powdered milk \\
\hline Dairy products & $\begin{array}{l}\text { Yoghurts; prato cheese, mozzarella and } \\
\text { white; cream cheese }\end{array}$ \\
\hline $\begin{array}{l}\text { Breads and } \\
\text { cookies }\end{array}$ & $\begin{array}{l}\text { Bread, french bread; Maisena } ® \text {, Maria } ® \text {, } \\
\text { milk, water and salt cookies }\end{array}$ \\
\hline Cake & Regular cake or chocolate with no icing \\
\hline $\begin{array}{l}\text { Cereal and } \\
\text { starchy }\end{array}$ & 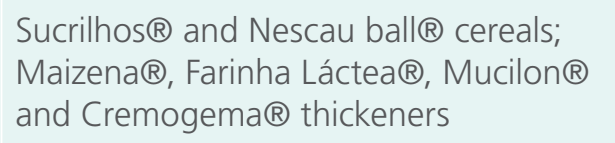 \\
\hline French fries & French fries \\
\hline Fatty lunches & $\begin{array}{l}\text { Chips, cheese bread, pastry, drumstick, } \\
\text { esfirra, pizza, sandwiches, hamburger }\end{array}$ \\
\hline Cookies & Cookie, wafer \\
\hline Chocolate & Chocolate bar, bonbon \\
\hline $\begin{array}{l}\text { Soda/artificial } \\
\text { juice }\end{array}$ & Soda; Tang® artificial juice \\
\hline Sugar & $\begin{array}{l}\text { Nescauß and Toddy® instant chocolate } \\
\text { powder; sugar }\end{array}$ \\
\hline Butter & Butter \\
\hline Coffee & Coffee with sugar \\
\hline
\end{tabular}


tistically significant. The analyses were performed using the Statistical Package for the Social Sciences (SPSS) version 20.0.

The research was approved by the Research Ethics Committee of the College of Public Health, University of São Paulo ( $\left.n^{\circ} 773287,2014\right)$. The person responsible authorized the participation of children in the data collection by signing the free consent form.

\section{Results}

The sample was characterized by children whose mothers had over 9 years of formal education, with a income of 1 to 2 minimum wages and with almost $30 \%$ of households in receipt of $\mathrm{PBF}$, receiving approximately $1 / 5$ of the minimum wage ( $R \$ 133$; 95\% Cl: 121-170). As for $\mathrm{Fl}, 26 \%$ of households were classified as having mild $\mathrm{Fl}, 13.3 \%$ with moderate $\mathrm{FI}$ and $1.9 \%$ as having severe $\mathrm{Fl}$, demonstrating that almost $60 \%$ were in household FS. It was verified that overweight/obesity was present in $6.8 \%$ of pre-schoolers (Table 2).

Table2. Pre-school distribution according to demographic, socioeconomic, food insecurity and nutritional condition, Taubaté, São Paulo, Brazil, 2014

\begin{tabular}{|l|c|c|}
\hline \multicolumn{1}{|c|}{ Variable } & n & $\%$ \\
\hline Gender & & \\
\hline Male & 140 & 45.5 \\
\hline Female & 168 & 54.5 \\
\hline Age & & \\
\hline 24 to 35 months & 109 & 35.4 \\
\hline 36 to 48 months & 199 & 64.6 \\
\hline Maternal schooling & & \\
\hline$\leq 5$ years of study & 38 & 12.4 \\
\hline 6 to 8 years of study & 62 & 20.2 \\
\hline 9 to 11 years of study & 119 & 38.8 \\
\hline$\geq 12$ years of study & 88 & 28.7 \\
\hline
\end{tabular}

\begin{tabular}{|l|c|c|}
\hline \multicolumn{1}{|c|}{ Variable } & n & $\%$ \\
\hline Family Income & & \\
\hline$<1$ minimum wage & 36 & 12.0 \\
\hline 1 to 2 minimum wages & 117 & 38.9 \\
\hline 2 to 3 minimum wages & 87 & 28.9 \\
\hline$\geq 3$ minimum wages & 61 & 20.3 \\
\hline Programa Bolsa Família beneficiaries & & \\
\hline Yes & 90 & 29.2 \\
\hline No & 218 & 70.8 \\
\hline Food Insecurity Scale & & \\
\hline Food and nutritional safety & 181 & 58.8 \\
\hline Light food insecurity & 80 & 26.0 \\
\hline Moderate food insecurity & 41 & 13.3 \\
\hline Severe food insecurity & 6 & 1.9 \\
\hline BMl/Age & & \\
\hline$<+2.00$ z-scores & 19 & 6.2 \\
\hline$\geq+2.00$ z-scores & Source: Research data \\
\hline
\end{tabular}

From the habitual consumption of the population, it was possible to determine five DPs, named according to their highest factor, which explained $39.5 \%$ of the total variance of the data, with a KMO of 0.675 and a BTS $p \leq 0.001$. The "Western" pattern was composed of fatty and/or sugary foods, with a predominance of ultra-processed foods. The "Fruits and Vegetables" pattern consisted of a diet high in fruits, vegetables, fish, cereals and tubers. The "Prudent" pattern was composed of meats, pasta and vegetables. The pattern predominantly rich in milk and sugary ingredients for the preparation of bottles was termed "Dairy". Finally, the "Traditional" eating pattern included typical Brazilian foods, such as rice, coffee and beans (Table 3 ).

The factors associated with DPs in the bivariate analysis are presented in Table 3. It should be noted that the model for the "Western" pattern includes children in FS/mild Fl; the "Fruits and Vegetables" DP is associated with high-income families and FS; 
Table 3. Distribution of factor loadings for the five identified food standards for pre-school. Taubaté. São Paulo. Brazil. 2014.

\begin{tabular}{|c|c|c|c|c|c|}
\hline \multirow{2}{*}{$\begin{array}{l}\text { Food groups } \\
\text { and items }\end{array}$} & \multicolumn{5}{|c|}{ Food Pattern } \\
\hline & Western & $\mathrm{FV} *$ & Prudent & Dairy & Traditional \\
\hline Fatty lunches & 0.690 & & & & \\
\hline Sausages & 0.587 & & & & \\
\hline French-fries & 0.567 & & & & \\
\hline Chocolate & 0.545 & & & & \\
\hline $\begin{array}{l}\text { Dairy } \\
\text { products }\end{array}$ & 0.529 & 0.402 & & & \\
\hline $\begin{array}{l}\text { Soda/Artificial } \\
\text { juice }\end{array}$ & 0.502 & & & & \\
\hline Cookies & 0.494 & & & & \\
\hline Fruits & & 0.689 & & & \\
\hline Vegetables & & 0.613 & & & \\
\hline Legumes & & 0.556 & 0.406 & & \\
\hline $\begin{array}{l}\text { Cereal e } \\
\text { starchy }\end{array}$ & & 0.493 & & & \\
\hline Fish & & 0.468 & & & \\
\hline
\end{tabular}

no association was found between the "Prudent" DP and the variables studied; the "Dairy" DP is associated with low-income families, moderate/severe $\mathrm{Fl}$ and with low-schooled mothers; finally, the "Traditional" pattern includes children with overweight/ obesity, low-educated mothers, low family income, benefiting from the income transfer programme, i.e. PBF, and moderate/severe $\mathrm{Fl}$.

In logistic regression analysis (Table 4), after adjusting each DP in relation to independent varia-

\begin{tabular}{|c|c|c|c|c|c|}
\hline \multirow{2}{*}{$\begin{array}{c}\text { Food groups } \\
\text { and items }\end{array}$} & \multicolumn{5}{|c|}{ Food Pattern } \\
\hline & Western & $\mathrm{FV}^{*}$ & Prudent & Dairy & Traditiona \\
\hline Meats & & & 0.682 & & \\
\hline Tubers & & 0.422 & 0.477 & & \\
\hline Pasta & & & 0.460 & & \\
\hline Chicken & & & 0.427 & & \\
\hline Sugars & & & & 0.691 & \\
\hline Milk & & & & 0.666 & \\
\hline Instant noodles & & & & 0.434 & \\
\hline Rice & & & & & 0.601 \\
\hline Coffee & & & & & 0.543 \\
\hline Beans & & & & & 0.515 \\
\hline Total of items & 7 & 7 & 5 & 3 & 3 \\
\hline Eigenvalue & 2.55 & 2.44 & 1.71 & 1.65 & 1.51 \\
\hline Variance (\%) & 10.20 & 9.77 & 6.84 & 6.61 & 6.05 \\
\hline $\begin{array}{l}\text { Accumulated } \\
\text { variance (\%) }\end{array}$ & 10.20 & 19.97 & 26.81 & 33.42 & 39.47 \\
\hline
\end{tabular}

* Fruits and Vegetables. Principal Component Analysis - Rotation Method: Varimax with Kaiser normalization. KMO: 0.675; BTS $\leq 0.001$; Cronbach's alpha $\geq 0.60$

bles and the other DPs, significant associations only remained for the "Western" DP with a protective effect against moderate/severe FI (OR: 0.46; 95\% CI $0.23-0.9 ; p=0.02$ ) and for the "Traditional" DP, for which there was a significant relationship with families that have the benefit of PBF, in addition to a greater risk of children being overweight/obese (OR: 3.68; 95\% Cl: 1.14-11.86; $p=0.03$ ).

Table 4. Pre-school distribution by scores categorized feeding patterns in medians and demographic, socioeconomic, food insecurity and nutritional ccondition characteristics. Taubaté. São Paulo. Brazil. 2014.

\begin{tabular}{|c|c|c|c|c|c|c|c|c|c|c|}
\hline \multirow{2}{*}{ Variables } & \multicolumn{2}{|c|}{ Western } & \multicolumn{2}{|c|}{ FV } & \multicolumn{2}{|c|}{ Prudent } & \multicolumn{2}{|c|}{ Dairy } & \multicolumn{2}{|c|}{ Traditional } \\
\hline & $<\mathrm{P} 50$ & $\geq P 50$ & $<$ P50 & $\geq$ P50 & $<$ P50 & $\geq$ P50 & $<$ P50 & $\geq$ P50 & $<$ P50 & $\geq$ P50 \\
\hline Gender & & $P=1.0$ & & $P=0.49$ & & $\mathrm{P}=0.82$ & & $P=0.11$ & & $P=0.89$ \\
\hline Male & 50.0 & 50.0 & 52.1 & 47.9 & 49.3 & 50.7 & 45.0 & 55.0 & 50.7 & 49.3 \\
\hline Female & 50.0 & 50.0 & 48.2 & 51.8 & 50.6 & 49.4 & 54.2 & 45.8 & 49.4 & 50.6 \\
\hline
\end{tabular}




\begin{tabular}{|c|c|c|c|c|c|c|c|c|c|c|}
\hline \multirow{2}{*}{ Variables } & \multicolumn{2}{|c|}{ Western } & \multicolumn{2}{|c|}{ FV } & \multicolumn{2}{|c|}{ Prudent } & \multicolumn{2}{|c|}{ Dairy } & \multicolumn{2}{|c|}{ Traditional } \\
\hline & $<$ P50 & $\geq$ P50 & $<$ P50 & $\geq$ P50 & $<$ P50 & $\geq$ P50 & $<$ P50 & $\geq$ P50 & $<\mathrm{P} 50$ & $\geq$ P50 \\
\hline \multicolumn{2}{|l|}{ Age } & $P=0.07$ & & $P=0.91$ & & $P=0.91$ & & $P=0.12$ & & $P=0.28$ \\
\hline $\begin{array}{l}24 \text { a } 35 \\
\text { months }\end{array}$ & 56.9 & 43.1 & 49.5 & 50.5 & 49.5 & 50.5 & 56.0 & 44.0 & 54.1 & 45.9 \\
\hline $\begin{array}{l}36 \text { a } 48 \\
\text { months }\end{array}$ & 46.2 & 53.8 & 50.3 & 49.7 & 50.3 & 49.7 & 46.7 & 53.3 & 47.7 & 52.3 \\
\hline \multicolumn{2}{|c|}{ Maternal schooling } & $P=0.31$ & & $P=0.24$ & & $P=0.84$ & & $P=0.01$ & & $P=0.02$ \\
\hline $\begin{array}{l}<9 \text { school } \\
\text { years }\end{array}$ & 46.0 & 54.0 & 55.0 & 45.0 & 51.0 & 49.0 & 40.0 & 60.0 & 40.0 & 60.0 \\
\hline $\begin{array}{l}\geq 9 \text { school } \\
\text { years }\end{array}$ & 52.2 & 47.8 & 47.8 & 52.2 & 49.8 & 50.2 & 55.1 & 44.9 & 54.6 & 45.4 \\
\hline \multicolumn{2}{|c|}{ Family income } & $P=0.61$ & & $P=0.14$ & & $P=0.98$ & & $P=0.16$ & & $P=0.08$ \\
\hline < 1 M.W. & 52.8 & 47.2 & 61.1 & 38.9 & 50.0 & 50.0 & 38.9 & 61.1 & 36.1 & 63.9 \\
\hline$\geq 1$ M.W. & 48.3 & 51.7 & 47.9 & 52.1 & 50.2 & 49.8 & 51.3 & 48.7 & 51.7 & 48.3 \\
\hline \multicolumn{2}{|c|}{ PBF Beneficiaries } & $P=0.21$ & & $P=0.62$ & & $P=0.80$ & & $P=0.21$ & & $P=0.001$ \\
\hline Yes & 44.4 & 55.6 & 52.2 & 47.8 & 48.9 & 51.1 & 44.4 & 55.6 & 35.6 & 64.4 \\
\hline No & 52.3 & 47.7 & 49.1 & 50.9 & 50.5 & 49.5 & 52.3 & 47.7 & 56.0 & 44.0 \\
\hline \multicolumn{2}{|c|}{ Food Insecurity Scale } & $P=0.04$ & & $P=0.08$ & & $P=0.87$ & & $P=0.15$ & & $P=0.02$ \\
\hline $\begin{array}{l}\mathrm{FS} \text { and } \\
\text { mild } \mathrm{FI}\end{array}$ & 47.5 & 52.5 & 47.9 & 52.1 & 49.8 & 50.2 & 51.7 & 48.3 & 52.9 & 47.1 \\
\hline $\begin{array}{l}\text { Moderate } \\
\text { and severe } \\
\mathrm{FI}\end{array}$ & 63.8 & 36.2 & 61.7 & 38.3 & 51.1 & 48.9 & 40.4 & 59.6 & 34.0 & 66.0 \\
\hline \multicolumn{2}{|l|}{ BMI/Age } & $P=0.24$ & & $P=0.24$ & & $P=0.81$ & & $P=0.24$ & & $P=0.01$ \\
\hline $\begin{array}{l}<+2.00 \\
z \text {-scores }\end{array}$ & 49.1 & 50.9 & 49.1 & 50.9 & 49.8 & 50.2 & 50.9 & 49.1 & 51.9 & 48.1 \\
\hline $\begin{array}{l}z+2.00 \\
z \text {-scores }\end{array}$ & 63.2 & 36.8 & 63.2 & 36.8 & 52.6 & 47.4 & 36.8 & 63.2 & 21.1 & 78.9 \\
\hline
\end{tabular}

\section{Discussion}

The socioeconomic indicators of the sample (Table 2) confirm the official data of the city of Taubaté, which is part of the metropolitan region of the Paraíba Valley and the North Coast, in the State of São Paulo, Brazil. More years of maternal schooling and a higher income of the families investigated were associated with a low rate of illiteracy. In addition, the population has good basic sanitation indicators in terms of appropriate coverage of garbage collection (99.78\%), water supply (98.60\%) and sewerage $(95.93 \%)$, justifying the HDI value of 0.800 , which is greater than that observed in Brazil as a whole and in São Paulo State more broadly. Thus, this investigation of food consumption habits, nutritional condition and food and nutritional security refers to a population with favourable living conditions. 
The food consumption described indicates that the most common pattern in pre-school nutrition in this study is the "Western" DP, given that the percentage value of variance explains the highest percentage of items and food groups aggregated in this factor (Table 3). This DP features high consumption of ultra-processed foods in preference to fresh or minimally processed foods in the population [12]. This means greater energy intake, involving a higher content of saturated and trans fats and sugar [13]. Other researchers have found the same trend among pre-schoolers [1, 5, 6], children over five years and adolescents [14, 15], albeit using different terms such as "unhealthy food", "snacks", "goodies" or "fast food".

In general, the food consumption patterns of children suffer from the direct influences of their life experiences in terms of families, health professionals and the media, who often have considerable power over food preferences during infancy, such as a short duration of breastfeeding, the use of cow's milk and the consumption of processed foods [16]. These choices of unhealthy foods are widely accepted by children, both owing to their flavour and the power of the media selling "pseudo-healthy" products [15]. The latter exploit social relations involving the act of eating, namely that obtaining food can be hindered or facilitated by the social context [6, 14]. This becomes evident when analysing the early introduction of fast food, sausages and sweets in baby food, this being a reflection of the urban way of life and a globalized perspective, in which fresh food is replaced with industrialized products [17].

Compatible with the analysis, the value $p<0.20$ (Table 4) indicates that it is important and feasible to consider associations between DPs and FI in a more detailed manner as families in a state of FS/mildFI constitute "Western" and "Fruits and Vegetables" DPs, demonstrating a conceptual contradiction, where FS is associated with unhealthy foods and mild FI with healthy foods. However, this relationship may indicate a socioeconomic characte- ristic. Thus, this discussion will not be settled only through statistically significant associations, which involve the loss of some nuances of food consumption and its relationship with Fl. It can be assumed from the data and theoretical knowledge that families in FS appear to correspond to the pattern "Fruits and Vegetables", with the "Western" pattern being related to mild FI and the "Traditional" and "Dairy" patterns with moderate/severe $\mathrm{FI}$.

As observed in the "Western" pattern, there is in mild FI a loss in the nutritional quality of food, as well as a reduced consumption of foods rich in proteins of high biological value, in addition to the high consumption of high-calorie foods [18]. Even in situations of FS, some families with access to food are not guaranteed a healthy diet [19]. In particular, perhaps due to lack of information, those families in favourable circumstances, which should have the status of FS, are actually in mild household Fl, unable to choose good quality food and buying food that is nutritionally poorer or foods that represent social status [1] .

In counterpoint, the beneficiaries of the PBF, who are individuals in high socioeconomic vulnerability and dependent on income transfer from the government to improve their conditions of life, are almost twice as likely to have the "Traditional" DP (Table 4), such as rice, coffee and beans, consumed by the Brazilian population, often due to cultural aspects, cost and availability, together with the consumption of ultra-processed food, such as instant noodles.

These findings concerning the "Traditional" DP are in line with the consumption presented in a survey conducted in Brazil [19] and United States [20], which also observed a less varied and unhealthy diet among families in the most severe situations of $\mathrm{Fl}$. Reinforcing this fact, other authors have noted that children in moderate/severe $\mathrm{Fl}$, exhibiting monotony in food consumption or the "Traditional" DP, are predominantly from low-income families, with basic maternal schooling $[1,5,14]$. These findings corroborate with Canadian study that correlates the food 
insecurity a lower mean number of different food items [21] and with the national surveys in South Africa, that show the a trend in poorer households in low mean scores for diversity and variety dietary [22].

The consumption of traditional foods mixed with other foods from a globalized, highly industrialized culture, such as instant noodles, can be understood from the perspective of poor families in which there is a convergence between purchasing power and their children's preferences for certain foods. This may lead to inappropriate children's food consumption practices, resulting in the need to include in the context of discussions concerning DPs broader reflections on social and emotional aspects in the obtainment and consumption of food by families by children and adolescents, especially those in socioeconomic vulnerability, were more likely to eat some less healthful types of food $[20,23]$.

Regardless of the degree of $\mathrm{Fl}$, families exhibit more inclusion of foods with high energy content and reductions in food of nutritional value, such as fruits, vegetables and legumes19, leading to a lack of the complex carbohydrates, fibres, minerals and vitamins that are important in the prevention of chronic non-communicable diseases, such as obesity [24].

Thus, the results strongly suggest a real and high risk for pre-schoolers consuming the "Traditional" and "Western" DPs. In particular, they may present cardiovascular complications that persist into adulthood, such as hypertension, dyslipidaemia and diabetes [15].

One of the main limitations in identifying food standards derives from the subjectivity that must be assumed by the researcher, who makes arbitrary decisions in the phase of analysis, the formation of food groups, the number of factors retained, the type of rotation and especially the assigning of food standards. However, the detailing of the methodology mitigates possible errors in interpretation, clarifying the decisions taken and their justifi- cations. Thus, we have to list the advantages of the data collection approach used: in the case of the food frequency questionnaire, this is an instrument which has low requirements in terms of cost and is applied by trained and experienced researchers; it is a relatively simple tool and allows the collection and analysis of data, requiring little time to gain knowledge of the feeding habits of a population.

As children's eating habits are formed and incorporated on a long-term basis, depending on the phase of development and growth, maintaining inadequate dietary patterns can lead to the emergence of health complications in later life1, such as excess weight and other chronic diseases that are a great social and financial burden on the country.

\section{Conclusion}

Western and Traditional DPs are qualitatively and quantitatively inadequate, regardless of family income condition and maternal education. Thus, public actions to combat unfavourable DPs and deleterious effects on health are important and indispensable to prevent chronic diseases.

\section{Funding}

This research did not receive any specific grant from funding agencies in the public, commercial, or notfor-profit sectors.

\section{Acknowledgements}

We thank Beatriz Bebiano for the grammar review revising the English language usage. There was no funding for the development of research.

\section{Conflict of interest}

The authors declare that they have no conflict of interest.

\section{Author Contributions}

Conceived and designed the experiments: Rocha EMB, Abreu LC, Vieira PD, Sorpreso ICE, Szarfarc 
SC. Performed the experiments: Rocha EMB, Szarfarc SC. Analyzed the data: Rocha EMB, Abreu LC, Vieira PD, Sorpreso ICE, Szarfarc SC. Contributed analysis tools: Rocha EMB, Abreu LC, Vieira PD, Sorpreso ICE, Szarfarc SC. Wrote the paper: Rocha EMB, Abreu LC, Vieira PD, Sorpreso ICE, Szarfarc SC. Read and approved the last version of the manuscripts: Rocha EMB, Abreu LC, Vieira PD, Sorpreso ICE, Szarfarc SC

\section{References}

1. Nobre LN, Lamounier JA, Franceschini SCC. Preschool children dietary patterns and associated factors. J Pediatr. 2012; 88(2):129-36. doi:10.2223/JPED.2169; PMID: 22421989

2. Hu FB. Dietary pattern analysis: a new direction in nutritional epidemiology. Curr Opin Lipidol. 2002; 13(1):3-9. PMID: 11790957

3. Gigante DP, Dias-da-Costa JS, Olinto MTA, Menezes AMB, Macedo S. Adult obesity in Pelotas, Rio Grande do Sul, Brazil, and the association with socioeconomic status. Cad Saúde Pública. 2006; 22(9):1873-9. doi: 10.1590/S0102-311X2006000900018.

4. Marinho SP, Martins IS, Perestrelo JPP, Oliveira DC. Obesity in adults from impoverished segments of the society. Rev Nutr. 2003; 16(2):195-201. doi:10.1590/S1415-52732003000200006.

5. Gatica G, Barros AJD, Madruga S, Matijasevich A, Santos IS. Food intake profiles of children age 12, 24 and 48 months from the 2004 Pelotas (Brazil) birth cohort: an exploratory analysis using principal components. Int J Behav Nutr Phys Act. 2012; 9:43. doi:10.1186/1479-5868-9-43; PMID: 22510615; PMCID: PMC3424118.

6. Sichieri LR, Castro JFG, Moura AS. Factors associated with dietary patterns in the urban Brazilian population. Cad Saúde Pública. 2003; 19(Suppl 1):S44-53. doi:10.1590/S0102311X2003000700006; PMID: 12886435.

7. Brazilian Institute of Geography and Statistics. National Household Sample Survey. Brasília; 2013. [cited 2015 Feb 10]. Available from: http://www.ibge.gov.br/home/estatistica/ populacao/seguranca alimentar 2013/

8. Pérez-Escamilla R, Segall-Corrêa AM, Maranha LK, Sampaio MFA, Marín-León L, Panigassi G. An adapted version of the U.S. Department of Agriculture Food Insecurity Module is a valid tool for assessing household food insecurity in Campinas, Brazil. J Nutr. 2004; 134(8):1923-8. PMID: 15284377.

9. Brazilian Health Ministry. Guidelines for collect and analysis of anthropometric data in health services. Brasilia; 2011. [cited 2014 Apr 27] Available from: http://bvsms.saude. gov.br/bvs/publicacoes/orientacoes coleta analise dados antropometricos.pdf
10. World Health Organization. WHO Multicentre Growth Reference Study Group. WHO child growth standards: length/height-forage, weight-for-age, weight-for-length, weight-for-height and body mass index-for-age: methods and development. Geneva; 2006. [cited 2008 Aug 10]. Available from: http://www.who.int/ childgrowth/standards/Technical report.pdf?ua=1

11. Colucci ACA, Philippi ST, Slater B. Development of a food frequency questionnaire for children aged 2 to 5 years. Rev Bras Epidemiol. 2004; 7(4):393-401. doi:10.1590/S1415$790 \times 2004000400003$.

12. Levy RB, Claro RM, Mondini L, Sichieri R, Monteiro CA. Regional and socioeconomic distribution of household food availability in Brazil, in 2008- 2009. Rev Saúde Pública. 2012; 46(1):6-15. doi: 10.1590/S0034-89102011005000088; PMID: 22183512.

13. Louzada MLC, Martins APB, Canella DS, Baraldi LG, Levy RB, Claro RM, et al. Ultra-processed foods and the nutritional dietary profile in Brazil. Rev Saúde Pública. 2015; 49:38. doi: 10.1590/S0034-8910.2015049006132; PMID: 26176747; PMCID: PMC4544452.

14. D’Innocenzo S, Marchioni DML, Prado MS, Matos SMA, Pereira SRS, Barros AP, et al. The socio-economic conditions and patterns of food intake in children aged between 4 and 11 years: the SCAALA study - Salvador/ Bahia. Rev Bras Saúde Matern Infant. 2011; 11(1):41-9. doi: 10.1590/S1519-38292011000100005.

15. Gama SR, Carvalho MS, Chaves CRMM. Childhood prevalence of cardiovascular risk factors. Cad Saúde Pública. 2007; 23(9):2239-45. doi: 10.1590/S0102-311X2007000900032; PMID: 17700959.

16. Caetano MCC, Ortiz TT, Silva SGL, Souza FIS, Sarni ROS. Complementary feeding: inappropriate practices in infants. J Pediatr. 2010; 86(3):196-201. doi:10.2223/JPED. 1994; PMID: 20401426.

17. Tuma RCFB, Costa THM, Schmitz BAS. Dietary and anthropometric assessment of three pre-schools from Brasilia, Federal District, Brazil. Rev Bras Saúde Matern. Infant. 2005; 5(4):419-28. doi: 10.1590/S1519-38292005000400005.

18. Antunes MML, Sichieri R, Salles-Costa R. Food intake among children under three years of age in an area with high food insecurity. Cad Saúde Pública. 2010; 26(8):1642-50. doi:10.1590/ S0102-311X201000080001.7

19. Panigassi G, Segal-Corrêa AM, Marín-León L, Pérez-Escamilla R, Maranha LK, Sampaio MFA. Intra-family food insecurity and profile of food consumption. Rev Nutr. 2008; 21(Suppl):S135-44. doi:10.1590/S1415-52732008000700012. 
20. Bauer KW, Widome R, Himes JH, Smyth M, Rock BH, Hannan PJ, et al. High Food Insecurity and Its Correlates Among Families Living on a Rural American Indian Reservation. Am J Public Health. 2012; 102(7):1346-1352. doi:10.2105/AJPH.2011.300522.

21. Egeland GM, Williamson-Bathory L, Johnson-Down L, Sobol I. Traditional food and monetary access to market-food: correlates of food insecurity among Inuit preschoolers. Int J Circumpolar Health. 2011; 70(4):373-83. PMID: 21878183.

22. Labadarios D, McHiza ZJ, Steyn NP, Gericke G, Maunder EM, Davids YD, et al. Food security in South Africa: a review of national surveys. Bull World Health Organ. 2011; 89(12):891-9. doi: 10.2471/BLT.11.089243.

23. Lindsay AC, Ferarro M, Franchello A, La Barrera R, Machado MMT, Pfeiffer ME, et al Child feeding practices and household food insecurity among low-income mothers in Buenos Aires, Argentina. Ciên Saúde Coletiva. 2012; 17(3):661-669. doi:10.1590/S1413-81232012000300012

24. World Health Organization. Global strategy on diet, physical activity and health. Fifty-seventh world health assembly. Geneva; 2004. [cited 2006 Mar 23]. Available from: http://www.who.int/ dietphysicalactivity/strategy/eb11344/strategy english web.pdf

25. Monteiro CA, Cannon G, Moubarac JC, Martins AP, Martins CA, Garzillo J, et al. Dietary guidelines to nourish humanity and the planet in the twenty-first century. A blueprint from Brazil. Public Health Nutr. 2015; 18:1-12. doi: 10.1017/S1368980015002165

26. Machado EHS, Leone C, Szarfarc SC. Defi ciência de ferro e desenvolvimento cognitivo. Rev Bras Crescimento Desenvolvimento Hum. 2011; 21(2):368-73. DOI: http://dx.doi. org/10.7322/ihgd.20025

27. Alencar MSS, Barros SEL, Borges IS, Cavalcante KN, Melo MTSM, Nunes IFOC, et al. Adequacies and inadequacies in the anthropometric and dietetic profiles of preschool children. J Hum Growth Dev. 26(2): 234-242. Doi: http://dx.doi.org/10.7322/ jhgd.11929
Publish in International Archives of Medicine

International Archives of Medicine is an open access journal publishing articles encompassing all aspects of medical science and clinical practice. IAM is considered a megajournal with independent sections on all areas of medicine. IAM is a really international journal with authors and board members from all around the world. The journal is widely indexed and classified Q2 in category Medicine. 